\title{
MANAJEMEN GOOD CORPORATE GOVERNANCE PADA USAHA KECIL DAN MENENGAH BERBASIS SUMBER DAYA MANUSIA
}

\author{
Subandi \\ Universitas Islam Negeri Raden Intan Lampung. \\ Jl. Letkol H. Endro Suratmin, Kota Bandar Lampung, Lampung 35131 \\ E-mail: subandi@radenintan.ac.id
}

Ahmad Fauzan

Universitas Islam Negeri Raden Intan Lampung.

Jl. Letkol H. Endro Suratmin, Kota Bandar Lampung, Lampung 35131

E-mail:subansi@radenintan.ac.id

\begin{abstract}
\begin{tabular}{c|c|c}
\hline Received: & Revised: & Approved: \\
28/05/2018 & $15 / 07 / 2018$ & $19 / 09 / 2018$ \\
\hline
\end{tabular}

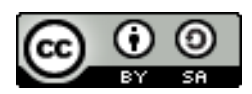

Manajemen Good Corporate Governance Pada Usaha Kecil Dan Menengah

Berbasis Sumber Daya Manusia Licensed Under a Creative Commons

Attribution-ShareAlike 4.0 International License
\end{abstract}

\begin{abstract}
The authors analyze the government's policies in developing people's economic interests of small and medium enterprises by using the principles of good governance. This study uses descriptive qualitative literature research using primary and secondary data sources. The authors urge that some policies should be taken within the framework of good government management, among others are: conducting program socialization and achieving strategies for the community; identifying human resources, ownership of sufficient capital; encouraging entrepreneurial spirit in small and medium-sized communities; and facilitating business customers (market segmentation), and the supervision and continuous improvement (quality Improvement).
\end{abstract}

Keywords: Good Governance, Management, and Enterpriser. 


\begin{abstract}
Abstrak
Penulis menganalisa bagaimana kebijakan pemerintah dalam mengembangkan minat ekonomi kerakyatan usaha kecil dan menengah dengan menggunakan prinsip Good Governance. Penelitian ini menggunakan jenis penelitian kualitatif deskriptif kepustakaan dengan menggunakan sumber data primer dan sekunder. Hasil penelitian penulis dalam langkahlangkah Kebijakan pemerintah dengan menggunakan manajemen good governance yang harus dilakukan adalah : 1). Melakukan sosialisai program dan strategi pencapainya kepada masyarakat, 2). Mengidentifikasi sumber daya manusia, pemilikian modal yang cukup, 3). Munculnya seangat jiwa kewirausahaan pada masyarakat kecil dan menengah4). Adanya pelanggan bisnis (sekmentasi pasar), dan adanya pengawasan serta perbaikan terus menerus (Quality Improvement).
\end{abstract}

Kata Kunci: Good Governance, Manajemen, dan Wiraswasta.

\title{
A. Pendahuluan
}

Bangsa Indonesia telah merdeka selama enam dasa warsa, selama tengang waktu itu belum banyak kebijakan yang berpihak kepada rakyat kecil, daerah terpinggir dan terpencil, sehingga nampak kesenjangan sosial dan ekonom muncul, sehingga sampai saat ini belum mampu keluar dari persoalan ekonomi, pengangguran, kemiskinan dan keterbelakangan. Data pada tahun 2014 Indonesia memiliki 0,24\% wirausaha dari populasi 248 juta jiwa, suatu negara akan mencapai kemakmuran jika 2\% dari jumlah penduduk menjadi pengusaha. Dengan berwirausaha suatu bangsa dapat menjaga pertumbuhan ekonomi dalam jangka panjang, maka dibutuhkan wirausaha (pengusaha) minimal 2\% dari jumlah penduduk, jika dianalogikan kurang lebih 5 juta penduduk menjadi pengusaha, maka pertumbuan ekonomi akan mampu stabil dan berkelanjutan perlu dibuat sebuah aturan atau kebijakan yang mampu mendorong kemauan masyarakat untuk berusaha dari tingkat yang paling bawah.

Usaha Kecil dan Menengah, salah satu bagian penting dari perekonomian suatu negara memiliki peranan penting dalam lajunya perekonomian masyarakat. Usaha kecil dan menegah ini juga sangat membantu negara atau pemerintah dalam hal penciptaan lapangan kerja baru, banyak tercipta unit unit kerja baru yang menggunakan tenaga-tenaga baru dapat mendukung pendapatan rumah tangga. 
Selain dari usaha kecil dan menengah juga memiliki fleksibilitas yang tinggi jika dibandingkan dengan usaha yang berkapasitas lebih besar. Usaha kecil yang menengah perlu mendapat perhatian yang khusus dan di dukung oleh informasi bisnis yang akurat, agar terjadi link bisnis yang terarah antara pelaku usaha kecil dan menengah dengan elemen daya saing usaha, yaitu jaringan pasar. Terdapat dua aspek yang harus dikembangkan untuk membangun jaringan antara pasar, aspek produsen dan konsemen.

Kendala yang dihadapi oleh sebagian besar usaha kecil dan menengah di Indonesia adalah rendahnya tingkat produktivitas, nilai tambah, dan kualitas produk. Harus diakui bahwa Indonesia saat ini usaha kecil dan menengah merupakan wadah para wirausahawan untuk menciptakan lapangan kerja bagi sebagian besar pekerja di Indonesia, akan tetapi kontribusi dalam output nasional masih dikatagorikan rendah. Hal ini dikarenakan, banyaknya tenaga kerja dibandingkan usaha yang tersedia khususnya usaha kecil dan menegah. Bila upah dijadikan produktivitas, upah rata-rata di usaha kecil umumnya berada dibawah upah minimum. Kondisi ini merefleksikan produktivitas sektor usaha kecil yang rendah bila di bandingkan dengan usaha yang lebih besar.

Di antara berbagai faktor penyebab adalah rendahnya tingkat penguasaan teknologi dan kemampuan wirausaha di kalangan usaha kecil dan menengah, hal tersebut menjadi isu yang mengemuka saat ini, sehingga pengembangan usaha kecil dan menengah secara parsial selama ini tidak banyak memberikan hasil yang maksimal terhadap peningkatan kinerja usaha kecil dan menengah. Perkembangan ekonomi secara lebih luas di Indonesia mengakibatkan tingkat daya saing Indonesia masih rendah diantara negara-negara tetangga kita seperti misalnya Singapura, Malaysia dan Thailand. Peningkatan produktivitas pada usaha kecil dan menengah, akan berdampak luas pada perbaikan kesejahteraan rakyat karena usaha kecil dan menengah adalah tempat dimana banyak orang menggantungkan sumber kehidupannya. Salah satu alternatif dalam meningkatkan produktivitas usaha kecil dan menegah adalah dengan melakukan modernisasi sistem usaha dan perangkat kebijakannya yang sistemik sehingga akan memberikan dampak yang lebih luas lagi 
dalam meningkatkan daya saing daerah. Para pelaku usaha kecil dan menengah masih konservatif terhadap informasi dan belum mempraktikkan aspek keterbukaan informasi secara memadai. Mayoritas usaha kecil dan menengah belum menjalankan usaha secara profesional dan belum memiliki perencanaan jangka panjang, sehingga ada risiko dari aspek keberlanjutan (sustainability).

Beberapa penelitian sebelumnya telah menganalisa Konsentrasi Regional UKM di Indonesia 1999-2001 yang membuktikan bahwa UKM memberikan kontribusi ratarata $90 \%$ terhadap penyerapan tenaga kerja dari semua sektor ${ }^{1}$, bagaimana pengembangan usaha kecil dan menengah dengan pendekatan kluster ${ }^{2}$, Perbaikan Manajemen UKM melalui Kartu Biaya Pesan Produksi dengan penetapan harga jual dan pengendalian biaya. Penerapan kartu ini juga sekaligus melengkapi program tahun sebelumnya yaitu tentang penggunaan Papan Informasi Produk dan Papan Informasi Stok, ${ }^{3}$

Dari sini penulis berusaha menganalisa bagaimana kebijakan pemerintah dalam mengembangkan minat ekonomi kerakyatan usaha kecil dan menengah dengan menggunakan manajemen Good Governance.

\section{B. Kebijakan Usaha Kecil dan Menengah di Indonesia}

Usaha kecil dan menengah mempunyai peran penting dan strategis dalam pembangunan ekonomi nasional. Selain berperan dalam pertumbuhan ekonomi dan penyerapan tenaga kerja, usaha kecil dan menengah juga berperan dalam mendistribusikan hasilhasil pembangunan. Usaha kecil dan menengah juga telah terbukti tidak terpengaruh terhadap krisis global. Ketika krisis menerpa pada periode tahun 1997-1998, hanya usaha kecil dan menengah yang mampu tetap berdiri kokoh. Data Badan Pusat Statistik memperlihatkan, pasca krisis ekonomi tahun 1997-1998 jumlah usaha kecil dan menengah tidak berkurang, justru meningkat terus,

${ }^{1}$ Dyah Ratih Sulistyastuti, “Dinamika Usaha Kecil dan Menengah (UKM) Analisis Konsentrasi Regional UKM di Indonesia 1999-200" 9, no. 2 (2004): 22.

2 M Kholid Mawardi, "Pengembangan Usaha Kecil dan Menengah (UKM)," t.t., 18 .

${ }^{3}$ Hasbi Yasin, Darwanto Darwanto, dan Hari Susanta Nugraha, "Perbaikan Manajemen UKM melalui Kartu Biaya Pesan Produksi," E-DIMAS 9, no. 1 (28 Maret 2018): 98, https://doi.org/10.26877/e-dimas.v9i1.1746. 
bahkan mampu menyerap 85 juta hingga 107 juta tenaga kerja sampai tahun 2012. ${ }^{4}$ Pada tahun itu, jumlah pengusaha di Indonesia sebanyak 56.539.560 unit. Dari jumlah tersebut, Usaha Mikro Kecil dan Menengah sebanyak 56.534.592 unit atau 99.99\%. Sisanya, sekitar 0,01\% atau 4.968 unit adalah usaha besar. Data tersebut membuktikan, usaha kecil dan menengah potensial bagi industri jasa keuangan, terutama bank untuk menyalurkan pembiayaan.

Usaha kecil dan menengah memiliki peranan penting dalam perekonomian di Indonesia. usaha kecil dan menengah memiliki proporsi sebesar 99,99\% dari total keseluruhan pelaku usaha di Indonesia atau sebanyak 56,54 juta unit. Usaha kecil dan menengah telah mampu membuktikan eksistensinya dalam perekonomian di Indonesia. Ketika badai krisis moneter melanda Indonesia di tahun 1998 usaha berskala kecil dan menengah yang relatif mampu bertahan dibandingkan perusahaan besar. Karena mayoritas usaha berskala kecil tidak terlalu tergantung pada modal besar atau pinjaman dari luar dalam mata uang asing. Sehingga, ketika ada fluktuasi nilai tukar, perusahaan berskala besar yang secara umum selalu berurusan dengan mata uang asing adalah yang paling berpotensi mengalami imbas krisis. Bisnis usaha kecil dan menengah menyumbang PDB (Produk Domestik Bruto) sekitar 60\% dan membuka lapangan pekerjaan bagi masyarakat ${ }^{5}$.

Selama tahun 2011 sampai 2012 terjadi pertumbuhan pada usaha kecil dan menengah serta penurunan pada usaha besar. Bila pada tahun 2011, usaha besar mencapai $41,95 \%$ tahun berikutnya hanya $40,92 \%$, turun sekitar 1,03\%. Pada usaha kecil dan menengah terjadi sebaliknya. Bila usaha menengah pada tahun 2011 hanya 13,46\%, pada tahun 2012 mencapai 13,59\%. Ada peningkatan sebesar $0,13 \%$. Berbeda dengan usaha kecil, ada sedikit penurunan dari tahun 2011. Pada tahun itu mencapai 9,94\% namun pada tahun 2012 hanya mencapai 9,68\%, artinya menurun sekitar $0,26 \%$. Peningkatan cukup besar terjadi pada usaha mikro, bila tahun 2011 hanya mencapai 34,64\%, pada tahun 2012 berhasil meraih 38,81\% terjadi peningkatan sebesar $4,17 \%$.

${ }^{4}$ Profil Bisnis Usaha Mikro, Kecil dan Menengah (UMKM) (Kerjasama LPPI dengan Bank Indonesia, 2015), 1-3.

${ }^{5}$ Bank Indonesia, “data PDB," 2015, 17. 
Marsch, Schmieder, dan Aerssen menyatakan bahwa terjadi kesenjangan informasi dalam usaha kecil dan menengah ${ }^{6}$ Kesenjangan informasi antara usaha kecil dan menengah dan Bank timbul dari kurangnya catatan akuntansi usaha kecil dan menengah, laporan keuangan atau rencana bisnis yang kurang memadai, sehingga sulit bagi kreditor dan investor untuk usaha kecil dan menengah dinilai kelayakan kredit dari proposal usaha kecil dan menengah yang potensial. ${ }^{7}$ Dalam RPJM II 2010-2014, secara eksplisit dijelaskan bahwa sangat perlu untuk usaha kecil dan menengah meningkatkan dan memajukan serta menambah akses terhadap modal dan melaksanakan kebijakan pemihakan untuk memberikan ruang usaha bagi pengusaha kecil dan menengah. Pemerintah pusat dan daerah melalui berbagai kementerian atau lembaga melakukan program-program untuk peningkatan akses permodalan, produksi, pemasaran dan manajemen. Fakta menunjukkan bahwa akses modal usaha kecil dan menengah di Indonesia adalah perbankan dan investor individu. Salah satu permasalahan yang terungkap adalah belum adanya kesiapan fundamental pada usaha kecil dan menengah dimana sebagian besar perusahaan masih menjalankan usahanya secara konvensional dan belum menerapkan good corporate dan governance. Secara umum, pelaksanaan Corporate Governance yang baik menjadikan perusahaan memiliki kinerja yang lebih baik, kekurangan usaha kecil dan menengah adalah pelaksanaan Corporate Governance yang lemah. ${ }^{8}$ Para pelaku usaha kecil dan menengah masih konservatif terhadap informasi dan belum mempraktikkan aspek keterbukaan informasi secara memadai. Mayoritas usaha kecil dan menengah belum menjalankan usaha secara profesional dan belum memiliki perencanaan jangka panjang, sehingga ada risiko dari aspek keberlanjutan (sustainability).

${ }^{6}$ Marsch, K., Schmieder, C dan Aerssen , K.F., “Banking Consolidation and Small Business Finance Empirical Evidence" (2007).

7 Iorpev, L, “Does Bank Size Master to Smalland Medium Scale Enterprises (SMEs) Financingin Negeria?" 2(3) (2012): 9.

${ }^{8}$ Wahab, E. A. A., How, J. C. Y. dan Verhoeven, P, "The Impact of the Malaysian Code on Corporate Governance: Compliance, Institutional Investors, and Stock Performance." 3(2), (2007): 106-129. 
Pada Bab I pasal 1 UU No. 20 Tahun 2008 tentang Usaha Kecil dan Menengah, maka yang dimaksud dengan Usaha Kecil, dan Menengah adalah:

1. Usaha Mikro adalah usaha produktif milik orang perorangan dan atau badan usaha perorangan yang memenuhi kriteria Usaha Mikro sebagaimana diatur dalam Undang-undang ini.

2. Usaha Kecil adalah usaha ekonomi produktif yang berdiri sendiri, yang dilakukan oleh orang perorangan atau badan usaha yang bukan merupakan anak perusahaan atau bukan cabang perusahaan yang dimiliki, dikuasai, atau menjadi bagian baik langsung maupun tidak langsung dari Usaha Menengah atau Usaha Besar yang memenuhi kriteria Usaha Kecil sebagaimana dimaksud dalam Undang-Undang ini.

3. Usaha Menengah adalah usaha ekonomi produktif yang berdiri sendiri, yang dilakukan oleh orang perorangan atau badan usaha yang bukan merupakan anak perusahaan atau cabang perusahaan yang dimiliki, dikuasai, atau menjadi bagian baik langsung maupun tidak langsung dengan Usaha Kecil atau Usaha Besar dengan jumlah kekayaan bersih atau hasil penjualan tahunan sebagaimana diatur dalam Undang-Undang ini.

Berdasarkan definisi di atas maka pada intinya Usaha Kecil dan Menengah adalah suatu bentuk usaha ekonomi produktif yang dilakukan oleh orang perseorangan atau badan usaha perorangan yang memenuhi kriteria Usaha Mikro, Kecil, dan Menengah. Sebagaimana Pasal 19 UU No. 20 Tahun 2008 tentang usaha kecil dan menengah, pengembangan dalam bidang sumber daya manusia sebagaimana dimaksud dalam Pasal 16 ayat (1) huruf c dilakukan dengan cara: a). Memasyarakatkan dan memberdayakan kewirausahaan, b). Meningkatkan keterampilan teknis dan manajerial dan c).Membentuk dan mengembangkan lembaga pendidikan dan pelatihan untuk melakukan pendidikan, pelatihan, penyuluhan, motivasi dan kreativitas bisnis, dan penciptaan wirausaha baru.

Dari ketiga aspek tersebut berarti sumber daya manusia merupakan subyek yang terpenting dalam pengembangan Usaha Mikro, Kecil, dan menengah agar dapat menciptakan wirausaha yang mandiri dari masyarakat. Oleh karena itu masyarakat perlu diberdayakan untuk meningkatkan kualitas SDM sehingga 
dapat mempengaruhi kualitas produksi yang dihasilkan dalam rangka meningkatkan perekonomian masyarakat untuk kesejahteraan masyarakat.

Merujuk pada definisi welfare dari Howard Jones dalam Suharto9, tujuan utama pembangunan kesejahteraan sosial adalah penanggulangan kemiskinan dalam berbagai manivestasinya. "The achievement of social welfare means, first and faremost, the alleviation of proverty in its many manivesstations". Makna "kemiskinan dalam berbagai manivestasinya" menekankan bahwa masalah kemiskinan di sini tidak hanya merujuk pada "kemiskinan fisik", seperti rendahnya pendapatan (income proverty) atau rumah tidak layak huni, melainkan pula mencakup berbagai bentuk masalah sosial lain yang terkait dengannya, seperti anak jalanan, pekerja anak, perdagangan manusia, pelacuran, pekerja migran, termasuk di dalamnya menyangkut masalah kebodohan, keterbelakangan, serta kapasitas dan efektivitas lembaga-lembaga pelayanan sosial pemerintah dan swasta (LSM, Organisasi sosial, institusi lokal) yang terlibat dalam penanggulangan kemiskinan.

Penjelasan Spicker dalam Suharto ${ }^{10}$ mengenai konsep walfare juga membantu mempertegas substansi pembangunan kesejahteraan sosial dengan menyatakan bahwa walfare (kesejahteraan) dapat diartikan sebagai "well-being" atau "kondisi sejahtera". Namun walfare juga berarti "The provision of social service provided by the state" dan Certain menuliskan "of benefits, especially meansteasted social security, aimed at poor people". Artinya, pengembangan kesejahteraan sosial menunjuk pada pemberian pelayanan sosial yang dilakukan oleh negara atau jenis-jenis tunjangan tertentu, khususnya jaminan sosial yang ditujukan bagi orang miskin. Seperti di negara lain, maka pembangunan kesejahteraan sosial memfokuskan kegiatannya pada bidang, yaitu pelayanan sosial, perlindungan sosial, dan pemberdayaan masyarakat. Ketiga fokus kegiatan tersebut dilakukan dengan berdasar pada kebijakan atau strategi yang bermakna pencegahan, penyembuhan, dan pengembangan.

${ }^{9}$ Edi Suharto, Membangun Masyarakat Memberdayakan Rakyat (Kajian Strategis Pembangunan Kesejahteraan Sosial dan Pekerjaan Sosial). (Bandung: PT Refika Aditama, 2009), 9.

${ }^{10}$ Edi Suharto, 9. 
Sistem pemerintahan di Indonesia mengharuskan untuk menata secara mendasar tentang perekonomian yang berpihak kepada ekonomi kerakyatan dan bukan ekonomi kapitalis dengan mengamanatkan pada perundang-undanag yaitu pada UUD 1945 pada pasal 33 ayat (1) dan ayat (2) yaitu perekonomian disusun atas usaha bersama dengan azas kekeluargaan. Hal tersebut diperkuat dengan ditetapkannya Undang-undang nomor 25 tahun 1992 tentang Perkoperasian Indonesia dan Peraturan Menteri Koperasi dan usaha kecil dan menengah Republik Indonesia tentang rapat anggota koperasi. Penataan tersebut diharapkan berdampak pada perubahan sistem dan struktur. Sistem berkaitan dengan hubungan antar unsur atau elemen yang saling mempengaruhi dan berkaitan membentuk suatu totalitas. Sistem berkaitan dengan hubungan antar unsur atau elemen yang saling mempengaruhi dan berkaitan membentuk suatu totalitas. Perubahan pada satu elemen kiranya dapat mempengaruhi unsur lain dalam sistem itu sendiri. Struktur berhubungan dengan tatanan yang tersusun secara teratur dan sistematis. Sedangkan perubahan struktur mencakup mekanisme dan prosedur, sumber daya manusia, sarana dan prasarana, organisasi dan lingkungannya dalam kerangka pencapaian tujuan efisiensi penyelenggaraan pemerintahan.

Untuk meningkatkan daya saing usaha kecil dan menengah diperlukan langkah kongkrit seperti 1). Kebijakan yang memihak kepada usaha kecil dan menengah 2). Deregulasi kebijakan 3). Memberikan peluang pasar baik dalam negeri 4). Mendorong eksportir hasil produk usaha kecil dan menegah 5). Alih teknologi. Kemajuan ekonomi terkait dengan perkembangan penguasaan teknologi, sebagian terbesar bersifat statis atau tidak terkoordinasi dan dibangun di atas pengalaman. Juga bersifat kumulatif ( terbentuk secara 'incremental' dan dalam waktu tertentu ). Waktu penguasaan teknologi ini bergantung pada sektor industrinya dan proses akumulasinya memiliki kekhasaan produk. 


\section{Manajemen Good Governance pada Pengembangan Sumber Daya Manusia}

Di Indonesia, prinsip-prinsip GCG selalu dijadikan salah satu opsional manajemen sebuah perusahaan yang meliputi transparancy memiliki arti bahwa informasi yang bersifat material dan relevan harus disediakan oleh pihak manajemen, accountability berarti pengelolaan organisasi bisnis dilakukan dengan benar, tidak hanya untuk memenuhi kepentingan perusahaan namun juga mempertimbangkan kepentingan stakeholder, responsibility memiliki arti semua peraturan perundang-undangan harus ditaati oleh perusahaan dan pertanggung-jawaban sosial kepada lingkungan sekitar agar terjadi kesinambungan usaha untuk jangka panjang, indepedency berarti masing-masing organ perusahaan tidak saling mendominasi, pengelolaan perusahaan harus secara independen dan bebas dari pengaruh pihak lain, fairness memiliki arti bahwa hak - hak para pemangku kepentingan harus diberikan perhatian agar dapat meningkatkan kinerja perusahaan ke arah yang lebih efektif. Prinsipprinsip GCG digunakan untuk mengukur sejauh mana prinsip GCG telah diterapkan dalam manajerial perusahaan pada sumber daya manusia ${ }^{11}$

Pelaksanaan Good Corporate Governance (GCG) sangat diperlukan untuk membangun kepercayaan masyarakat dan dunia internasional sebagai syarat mutlak bagi dunia perbankan untuk berkembang dengan baik dan sehat. ${ }^{12} \mathrm{Hal}$ ini juga diperlukan untuk mengendalikan perilaku pengelola perusahaan agar tidak bertindak dengan menguntungkan dirinya sendiri, melainkan menguntungkan bagi pemilik perusahaan dengan menyamakan kepentingan antara pemilik perusahaan dengan mengelola perusahaan. ${ }^{13}$

Sumber Daya Manusia merupakan kemampuan terpadu dari daya pikir dan daya fisik yang dimiliki individu ${ }^{14}$. Pelaku dan sifatnya dilakukan oleh keturunan dan lingkungannya, sedangkan prestasi

${ }^{11}$ Zainul Arifin, Dasar-dasar Manajemen Bank Syariah (Jakarta: Pustaka Alvabet, 2005), 35.

${ }^{12}$ Nur Hidayati Setyani, “Pada Perbankan Syari'ah Di Indonesia,” 2012, 49.

${ }^{13}$ Yufenti Oktafia, "Pengaruh Good Corporate Governance," t.t., 19.

${ }^{14}$ Malayu Hasibuan, Manajemen Sumber daya Manusia (Jakarta: PT. Bumi Aksara, 2003), 224. 
kerjanya dimotivasi oleh keinginan untuk memenuhi kepuasannya. Sumber Daya Manusia di singkat SDM merupakan yang dimiliki setiap manusia. SDM terdiri dari daya fikir dan daya fisik setiap manusia. Tegasnya kemampuan setiap manusia ditentukan oleh daya fikir dan daya fisiknya. SDM atau manusia menjadi unsur utama dalam setiap aktivitas yang dilakukan. Peralatan yang handal atau canggih tanpa peran aktif SDM, tidak berarti apa-apa. Daya pikir adalah kecerdasan yang dibawa lahir (modal dasar) sedangkan kecakapan diperoleh dari usaha (belajar dan pelatihan). Kecerdasan tolok ukurnya Intelegence Quotient (IQ) dan Emotion Quality (EQ).

Menurut Abdurrahmat Fathoni ${ }^{15}$ Sumber Daya Manusia merupakan modal dan kekayaan yang terpenting dari setiap kegiatan manusia. Manusia sebagai unsur terpenting mutlak dianalisis dan dikembangkandengancara tersebut.Waktu, tenaga dan kemampuanya benar-benar dapat dimanfaatkan secara optimal bagi kepentingan organisasi, maupun bagi kepentingan individu.

Menurut Veithzal Rivai ${ }^{16}$, Manajemen Sumber Daya Manusia merupakan salah satu bidang dari manajemen umum yang meliputi segi-segi perencanaan, pengorganisasian, pelaksanaan dan pengendalian. Proses ini terdapat dalam fungsi atau bidang produksi, pemasaran, keuangan, maupun kepegawaian. Karena sumber daya manusia dianggap semakin penting perannya dalam pencapaian tujuan perusahaan, maka berbagai pengalaman dan hasil penelitian dalam bidang SDM dikumpulkansecarasistematisdalamapa yang disebutmanajemen sumber daya manusia. Istilah "manajemen" mempunyai arti sebagai kumpulan pengetahuan tentang bagaimana seharusnya memanage (mengelola) sumber daya manusia.

Berdasarkan beberapa pendapat mengenai manajemen dan sumber daya manusia tersebut, maka dapat ditarik gambaran secara sederhana mengenai pengertian Manajemen Sumber Daya Manusia (MSDM) yaitu segala bentuk kegiatan mengelola sumber daya manusia. Dari keseluruhan sumber daya yang tersedia dalam suatu organisasi, sumber daya manusia merupakan aspek yang paling

${ }^{15}$ Abdurrahman Fathoni, Organisasi dan Manajemen Sumber Daya Manusia (Jakarta: PT Rineka Cipta, 2006), 8.

${ }^{16}$ Veithzal Rivai, Manajemen Sumber Daya Manusia Untuk Perusahaan dari Teori ke Praktik (Jakarta: PT Raja Grafindo Persada, 2005), th. 
penting dikarenakan sumber daya manusia merupakan satu-satunya sumber daya yang memiliki akal, perasaan, keinginan, kemampuan, keterampilan, pengetahuan, dorongan, daya, dan karya.

Keberhasilan sebuah perusahaan bukan hanya tergantung dari permodalan secara riil yaitu berbentuk uang, namun ada hal penting lain yang juga berpengaruh adalah SDM yang ada dalam perusahaan tersebut. Mengelola Sumber Daya Manusia dalam perusahaan sangatlah penting. Dimana SDM sangat dibutuhkan dalam suatu perusahaan untuk sebuah kemajuan perusahaan tersebut. Sumber daya manusia dalam suatu perusahaan merupakan penentu yang sangat penting bagi keefektifan berjalannya kegiatan di dalam organisasi. Keberhasilan dan kinerja seseorang dalam suatu bidang pekerjaan banyak ditentukan oleh tingkat kompetensi, profesionalisme dan juga komitmennya terhadap bidang pekerjaan yang ditekuninya. Sebuah perusahaan dituntut untuk mampu meningkatkan kualitas sumber daya manusia yang ada.

Dalam era globalisasi persaingan merupakan hal yang semakin nyata terjadi dan kita saksikan, terlebih ditambah dengan berkembangnya teknologi informasi yang begitu cepat dan semakin canggih. Terdorong oleh kondisi tersebut, setiap organisasi baik yang bergerak dalam lingkup industri maupun jasa, baik yang berorientasi pada profit ataupun non-profit dituntut untuk mampu menggerakkan serta memberdayakan sumber daya yang dimilikinya seoptimal mungkin guna memperoleh hasil yang terbaik.

Strategi pengembangan SDM merupakan perencanan mengenai cara bagaimana kualitas dari sumber daya manusia yang dimiliki mampu berkembang ke arah yang lebih baik, meningkat kemampuan kerja, skill dan memiliki loyalitas yang baik terhadap organisasi. Pengembangan sumber daya manusia dibutuhkan untuk kelangsungan sebuah organisasi agar mampu berkembang secara lebih dinamis. Manusia adalah unsur terpenting dalam sebuah organisasi, manusia adalah penggerak dan pengelola dari sumber daya organisasi yang ada, sehingga tidak berlebihan menjadikan sumber daya manusia sebagai unsur yang layak mendapat prioritas lebih dari sumber daya organisasi yang lainnya sehingga sumber daya manusia yang ada memiliki kualitas yang terbaik, karena dengan 
memiliki sumber daya manusia yang terbaik maka daya saing atas organisasi tersebut akan semakin tinggi.

\section{GCG Mengembangkan Jiwa Wirausaha.}

Menumbuhkan jiwa kewirausahaan tidak cukup ditujukan semata mata kepada personil aparatur, melainkan juga harus didukung dengan pembentukan organisasi yang kondusif hal ini sejalan dengan dikemukakan Drukker dalam Jaswadi ${ }^{17}$ bahwa hampir setiap orang bisa menjadi wirausahawan. Sebaliknya wirausahawan bisa berubah menjadi birokrat, apabila organisasinya disusun untuk mendorong perilaku birokratis.

Kewirausahaan dapat dipandang sebagai institusi kemasyarakatan yang mengandung nilai-nilai dan dinyatakan dalam perilaku. Nilai dan perilaku itu merupakan dasar, sumber daya, tenaga penggerak, tujuan, siasat, kiat, proses dan hasil bisnis. Wirausaha adalah pelakunya. Pada masa lalu kewirausahaan dan wirausaha adalah urusan pengalaman langsung di lapangan. Hanya sedikit sekali yang masuk sebagai materi pelajaran formal di sekolah. Demikian juga pembahasan masalah kewirausahaan dan wirausaha dahulu biasanya dilakukan dengan pendekatan mikro, khususnya dari sudut sifat-sifat dan perilaku pribadi wirausaha. Saat ini pendekatan mikro dilengkapi dan dijelaskan dengan pendekatan makro yaitu faktor lingkungan dan faktor sosiologis lainnya seperti model Carol Moore dalam Bygrave ${ }^{18}$, khususnya kebijakan pemerintah untuk pembinaan pengembangan budaya kewirausahaan dan ketersediaan serta kesiapan sumber daya di masyarakat sendiri dalam arti fisik dan mental akhirnya akan menentukan ruang lingkup, intensitas dan profil perilaku kewirausahaan.

Entrepreneurship adalah adalah kewiraswastaan atau kewirausahaan yang terjadi dalam suatu perusahaan pribadi, sehingga pelakunya (wirausaha) memiliki kebebasan, dan tidak terikat oleh aturan-aturan yang akan "mengekang" perilakunya. Sedangkan intrapreneurship adalah perilaku kewirausahaan seseorang yang

${ }^{17}$ Jaswadi, Penerapan Good Governance pada Perusahaan Skala Kecil dan Menengah Non Go Public. (Malang: Politeknik Negeri Malang, 2016), 67.

${ }^{18}$ W.D. Bygrave, “"Small Business Managers' Attitudes Towards And Use Of Financial Sources,"” 2 (1995): 139-154. 
berada dalam suatu organisasi atau lembaga tertentu baik Pemerintah maupun swasta, sehingga mereka terikat oleh suatu peraturan atau perundang-undangan tertentu. Namun demikian keduanya memiliki karakteristik yang sama, perbedaannya hanyalah dalam aplikasinya karena situasi yang berbeda.

Kewirausahaan dalam konteks entrepreneurship didefinisikan bahwa "entrepreneurship is the creation of value through the creation of the organization"19 Jadi kewirausahaan adalah penciptaan nilai yang terjadi melalui penemuan, layanan, transaksi, teknologi, dan pemasaran bagi masyarakat, melalui pembentukan atau pengembangan suatu organisasi. Kao mengemukakan bahwa: "entrepreneurship is the attempt to create value through recognition of the business opportunity, the management of risk taking appropriate to the opportunity, and through the communicative and management skills to mobilize human, financial, and material resources necessary to bring a project to fruition. Artinya kewirausahaan adalah usaha menciptakan nilai melalui peluang bisnis baru, manajemen yang berani mengambil resiko yang sesuai dengan peluang yang ada, keterampilan manajemen yang komunikatif untuk memobilisasi orang-orang, dana, peralatan dan sumber daya lainnya, yang diperlukan agar pekerjaan berhasil guna. Dinyatakan dalam Hadits yang artinya: Rasulullah Muhammad SAW. bersabda bahwa manusia yang baik adalah manusia yang paling bermakna atau bermanfaat bagi manusia lainnya. Dari hadits ini dapat diturunkan beberapa sikap wirausaha muslim antara lain sebagai berikut :

Pertama, seorang wirausaha muslim selalu berpikir, berbuat, dan berusaha untuk sebanyak-banyaknya membantu orang lain. Ia mengamati lingkungannya, dan bertanya pada dirinya apa yang dapat aku perbuat untuk membantu orang lain.

Kedua, seorang wirausaha muslim lebih mementingkan masyarakat dibanding dengan kepentingan dirinya dan kelompoknya. Fokus perhatiannya adalah apa kebutuhan orang banyak yang dapat dilakukan olehnya, sehingga mereka mendapat kepuasan. Pedagang muslim berusaha memuaskan pelanggannya, dengan selalu berusaha memenuhi kebutuhan pelanggannya, oleh layanannya, dan jenis

${ }^{19}$ Suandi dan Y. Sri, Strategi Pengembangan Usaha Mikro Kecil dan Menengah di Provinsi Daerah Istimewa Yogyakarta (Yogyakarta: tp, 2011), 67. 
barang serta kualitasnya yang prima. Dalam pemasaran konsep ini disebut dengan customers focus, yaitu perilaku pedagang dalam upaya memuaskan pelanggannya.

Ketiga, seorang wirausaha mampu mengubah suatu masalah menjadi peluang. Gejala hidup boros yang terjadi dalam masyarakat dewasa ini, antara lain seperti, banyaknya model pakaian yang beraneka ragam, mendorong sikap masyarakat menjadi konsumeristis. Orang-orang merasa bergengsi bila mampu memakai sepatu dengan merek tertentu, atau mampu berbelanja di supermarket, atau makan di restoran asing, meskipun mereka harus mengorbankan uang yang lebih besar karena harga yang berlipat. Hal tersebut sebenarnya merupakan suatu masalah, baik bagi keluarga maupun bagi masyarakat, khususnya masyarakat yang tingkat ekonominya lemah. Bagi seorang wirausaha hal tersebut merupakan peluang bisnis, dan ini merupakan sikap wirausaha muslim untuk mengubah sikap masyarakat. Seorang wirausaha muslim sangat sedih melihat terjadinya konsumerisme di lingkungan masyarakat, karena pemborosan yang terjadi sebagai akibatnya, dan merupakan nilai dan sikap yang bertentangan dengan nilai dan sikap seorang mu'min yang kaaffah.

Oleh karena itu seorang wirausaha muslim dengan tekun mempelajari perkembangan mode yang terjadi secara global, observasi ke tempat-tempat perbelanjaan mewah, belajar mendesain yang sesuai dengan mode terkini, mempelajari bahan-bahan baku tekstil yang berkualitas dengan harga yang terjangkau. Kemudian ia luncurkan produk yang sesuai dengan model masa kini, tetapi dengan harga murah dan terjangkau oleh kaum ekonomi lemah. Ia ingin memuaskan pelanggannya, dengan kualitas barang yang prima dengan harga yang sangat terjangkau masyarakat luas. Ia memiliki idealisme yaitu ingin memerangi konsumerisme yang menggejala saat itu. Ia ingin bermakna dan bermanfaat bagi masyarakat luas, dalam memenuhi kebutuhan dan seleranya, serta mengubah sikapnya kembali kepada nilai dan sikap muslim yang ekonomis. Kegiatan tersebut menggambarkan adanya kemampuan untuk mengubah suatu masalah menjadi peluang dan mengupayakan peluang itu hingga "berbuah", baik bagi masyarakat luas maupun dirinya. 
Perguruan tinggi biasanya sarat dengan tugas-tugas berkarya dalam dunia ilmiah. Ada perguruan tinggi yang jadi pemimpin, peneliti, pembaharu, penemu, inovator dan pemandu karyakarya ilmiah. Tetapi banyak perguruan tinggi yang menghadapi kesenjangan komunikasi ilmiah, hanya bisa jadi konsumen karya ilmiah yang sudah out-of-date dan bertindak sebagai pengecernya. Paper singkat ini hendak menelusuri potensi dan peranan perguruan tinggi dan seberapa besar, jika ada, untuk memproyeksi masa depan kewirausahaan di Indonesia serta memberi alternatif jawaban terhadap satu tantangan besar yang dihadapkan kepada bangsa kita dewasa ini (seperti banyaknya tenaga kerja, lapangan kerja yang sangat terbatas, rendahnya produktivitas, masih belum optimalnya penggunaan sumber daya alam serta ketidakstabilan ekonomi). Apakah masih ada potensi yang belum dimanfaatkan, apakah masih mungkin ada pergeseran memfungsikan sebagian dari potensi itu untuk menjawab tantangan ini : membangkitkan kewirausahaan dan mengantar hadirnya pewirausaha yang mempunyai keunggulan bersaing di era pasar bebas.

Para ahli dan praktisi dewasa ini sepakat bahwa kewirausahaan dapat dipelajari. Sebagian besar dari mereka juga percaya bahwa kewirausahaan itu dapat diajarkan. Forumnya bisa formal atau non formal. Sistem penyampaian dan metode pengajarannya bisa bervariasi. Dengan hasil pendidikan itu, mereka menambah kekuatan generator terhadap bakat-bakat kewirausahaannya. Sudah lewat waktunya bagi pandangan atau pendapat bahwa kewirausahaan hanya soal bakat semta-mata. Sudah lewat juga waktunya bagi pandangan dan pendapat bahwa pewirausaha itu tabu dengan banyak aturan dan banyak rencana yang membatasi kebebasannya dan daya kreatifnya. Disamping infromasi dan pelajaran tentang kewirausahaan, pewirausaha dewasa ini mutlak memerlukan penguasaan prinsip-prinsip manajemen bisnis, yang berkedudukan atau berperan sebagai partnernya yang dapat saling membantu, memperkuat posisinya dan meningkatkan kemajuannya.

Tanpa penguasaan prinsip-prinsip manajemen bisnis, pewirausaha seakan-akan pincang. Pewirausaha dapat mempercayakan penerapan ketrampilan manajemen bisnis kepada yang dipercayanya. 
Manajemen strategik adalah sistem manajemen bisnis yang dianggap paling sejalan dengan gaya dan pendekatan pewirausaha. Manajemen strategik berorientasi dan berwawasan masa depan. Ia meluncurkan pendekatannya berdasarkan analisis kedepan. Ia menuntut visi-misiposisi-tujuan-strategi-aksi yang kreatif, adaptif dan dinamik. Dengan begitu, khususnya pelaku wirausaha baru yang karena masih terbatas pengalamannya belum terkenal sebagai pengambil keputusan dan tindakan tepat secara intuitif, dapat dibantu dalam putusan dan tindakannya dengan pemikiran yang berdasar konsep-konsep ilmiah.

Dalam kaitannya pada strategi pengembangan sumber daya manusia, Penerapan prinsip GCG yang baik dapat memengaruhi kinerja organisasi bisnis. Kinerja organsasi terdiri kinerja keuangan dan nonkeuangan. Secara fundamental kinerja perusahaan dapat tercermin dari kinerja keuangannya. Laporan keuangan merupakan data fundamental perusahaan yang digunakan untuk mengukur kinerja keuangan organisasi bisnis.

Kaen dalam Gede menyatakan "corporate governance pada dasarnya menyangkut masalah siapa yang seharusnya mengendalikan jalannya kegiatan korporasi dan mengapa harus dilakukan pengendalikan terhadap jalannya kegiatan korporasi $^{20}$. Yang dimaksud dengan "siapa" adalah para pemegang saham, sedangkan "mengapa" adalah karena adanya hubungan antara pemegang saham dengan berbagai pihak yang berkepentingan terhadap perusahaan. Pihak-pihak utama dalam corporate governance adalah pemegang saham, manajemen, dan dewan direksi. Pemangku kepentingan lainnya termasuk karyawan, pemasok, pelanggan, bank dan kreditor lain, regulator, lingkungan, serta masyarakat luas".

Adanya kegagalan beberapa perusahaan dan timbulnya kasus malpraktik keuangan akibat krisis tersebut adalah buruknya praktik Corporate Governance (CG). Karena hal tersebut GCG akhirnya menjadi isu penting, terutama di Indonesia yang merasakan pal-ing parah akibat krisis tersebut. Disamping itu, banyaknya kasus pelanggaran yang dil-akukan oleh perusahaan emiten di pasar modal yang

${ }^{20}$ Gede dan I Gusti, Pengaruh Prinsip-Prinsip Good Corporate Governance pada Kinerja Keuangan Koperasi di Kabupaten Klungkung (Bali: Fakultas Ekonomi dan Bisnis Universitas Udayana, 2016), 17. 
ditangani Badan Pengawas Pasar Modal dan Lembaga Keuangan (Bapepam-LK) menunjukkan rendahnya mutu praktik GCG di negara kita. Prinsip Dasar Good Corporate Governance Prinsip-prinsip dasar dari GCG, pada dasarnya memiliki tujuan untuk memberikan kemajuan terhadap kinerja suatu perusahaan.

Usaha kecil dan menengah sebagai penggerak ekonomi suatu wilayah bahkan dalam area yang lebih besar Negara. Pengusaha kecil, khususnya pengusaha produk kreatif dalam hal ini bidang fashion dan handycraft memerlukan manajemen dan tata kelola yang baik, karena sektor ini merupakan sektor yang selalu terpengaruh trend pasar sehingga para pengusaha di bidang ini memerlukan pendidikan dan pengalaman yang memadai untuk menjalankan usahanya. Para pelaku usaha mikro kecil menengah harus cermat melihat peluang ekspor produknya ke luar negeri.

Identifikasi sumber daya yang memiliki nilai lebih dan tidak memiliki nilai lebih pada usaha kecil dan menengah produk kreatif. Salah satu sumber daya yang memiliki nilai lebih yaitu inovasi, inovasi adalah kesuksesan ekonomi dan sosial berkat diperkenalkannya cara baru atau kombinasi baru dari cara-cara lama dalam menstransformasi input menjadi output yang menciptakan perubahan besar dalam hubungan antara nilai guna dan harga yang ditawarkan kepada konsumen dan atau pengguna, komunitas, sosialitas dan lingkungan. Inovasi dalam hal ini adalah praktik atau hasil nyata dari kreativitas yang dapat diterima oleh pasar. Inovasi dalam proses produksi dapat menawarkan nilai tambah yang berlipatlipat dan berpotensi menguntungkan bagi produsen beserta seluruh staf dan karyawannya.

Modal intelektual merupakan sumber daya yang memiliki nilai tambah pada usaha kecil dan menengah produk kreatif. Mengidentifikasi modal intelektual sebagai seperangkat sumber daya tak berwujud (kemampuan dan kompetensi) yang menggerakkan organisasi untuk menciptakan kinerja dan nilai perusahaan ${ }^{21}$. Seringkali modal intelektual didefinisikan sebagai sumber daya

${ }^{21}$ Bontis,N., Crossan, M dan Hulland, J., "Managing an Organizational Learning System by Aligning Stocks and Flows, : .," Journal of Management Studies 39, 2001. 
pengetahuan dalam bentuk karyawan, pelanggan, proses, atau teknologi yang dapat digunakan perusahaan dalam proses penciptaan nilai bagi perusahaan ${ }^{22}$. Secara umum, elemen-elemen dalam modal intelektual dibedakan dalam tiga kategori pengetahuan, yaitu pengetahuan yang berhubungan dengan karyawan (human capital), pengetahuan yang berhubungan dengan pelanggan (customer capital atau relational capital), dan pengetahuan yang berhubungan hanya dengan perusahaan (structural atau organizational capital). Ketiga kategori tersebut membentuk Intellectual Capital ${ }^{23}$. Komponenkomponen modal intelektual adalah sebagai berikut:

1. Human Capital adalah keahlian dan kompetensi yang dimiliki karyawan dalam memproduksi barang dan jasa serta kemampuannya untuk berhubungan baik dengan pelanggan. Termasuk dalam human capital yaitu pendidikan, pengalaman, keterampilan, kreatifitas dan perilaku. Human capital merepresentasikan modal pengetahuan individu organisasi yang dipresentasikan oleh karyawannya. Jika perusahaan berhasil dalam mengelola pengetahuan karyawannya maka hal tersebut dapat meningkatkan human capital. Human capital ini akan mendukung structural capital dan customer capital.

2. Structural Capital adalah infrastruktur yang dimiliki suatu perusahaan dalam memenuhi kebutuhan pasar. Termasuk dalam structural capital yaitu sistem teknologi, sistem operasional perusahaan, paten, merk dagang dan kursus pelatihan. Bontis ${ }^{24}$ menyebutkan structural capital meliputi seluruh pengetahuan selain pengetahuan yang dimiliki sumber daya manusia dalam organisasi seperti sistem informasi, struktur organisasi, proses manual, strategi perusahaan, rutinitas kegiatan, dan segala hal yang membuat nilai perusahaan lebih besar dari nilai materialnya.

3. Customer Capital adalah orang-orang yang berhubungan dengan perusahaan, yang menerima pelayanan yang diberikan oleh perusahaan tersebut. Elemen customer capital merupakan

${ }^{22}$ Bontis,N., Crossan, M dan Hulland, J., 15.

${ }^{23}$ B. Boekestein, "The relation between intellec- tual capital and intangible assets of phar- maceutical companies" Vol. 7 No.2 (2006).

24 Bontis, N., W. C. C. Keow and S. Richardson, "Intellectual capital and business performance in Malaysian industries" 1(1) (2000): 85-100. 
komponen modal intelektual yang memberikan nilai secara nyata. Customer capital membahas mengenai hubungan perusahaan dengan pihak di luar perusahaan seperti pemerintah, pasar, pemasok dan pelanggan, bagaimana loyalitas pelanggan terhadap perusahaan. Menurut Bontis customer capital adalah pengetahuan yang melekat dalam saluran pemasaran dan hubungan dengan pelanggan organisasi yang dikembangkan melalui bisnisnya ${ }^{25}$

\section{E. Simpulan}

Kebijakan pemerintah dengan pengembangan ekonomi kerakyatan usaha kecil dan menengah maka ada beberapa langkah yang dilakukan antara lain: Pemerintah sebagai penguasa dan penentu kebijakan yaitu menjadi raahmad bagi seluruh alam (rahmatan lil alamin) yakni terwujudnya kehidupan yang damai ,adil, makmur, sejahtera dan penuh kebahagiaan untuk mengapai umat terbaik (khairu ummah) dengan mengembangkan perekonomian usaha kecil dan menengah. , Kemampuan setiap manusia ditentukan oleh daya fikir dan daya fisiknya. Manusia menjadi unsur utama dalam setiap aktivitas yang dilakukan. Peralatan yang handal atau canggih tanpa peran aktif SDM. Daya pikir adalah kecerdasan yang dibawa lahir, sedangkan kecakapan diperoleh dari usaha (belajar dan pelatihan). Kecerdasan tolok ukurnya Intelegence Quotient (IQ) dan Emotion Quality $(E Q)$, Menentukan arah strategis dalam pembinaan dan pengembagan wirausaha melalui kebijakan pro rakyat kecil dan menengah, serta memberikan berlindungan kepastian hukum dan pemberian bantuan modal. Dan Teridentifikasinya Sumber daya yang mampu diupayakan oleh masyarakat pada usaha kecil dan menengah produk kreatif, Identifikasi sumber daya yang memiliki nilai tambah pada usaha kecil dan menengah. Salah satu sumber daya yang memiliki nilai tambah yaitu inovasi, inovasi adalah kesuksesan ekonomi dan sosial berkat diperkenalkannya cara baru atau kombinasi baru dari cara-cara lama dalam menstransformasi input menjadi output yang menciptakan perubahan besar dalam hubungan antara nilai guna dan harga yang ditawarkan kepada konsumen dan atau pengguna,

${ }^{25}$ Bontis,N., Crossan, M dan Hulland, J., "Managing an Organizational Learning System by Aligning Stocks and Flows, : .," 437-469. 
komunitas, sosial dan lingkungan. Secara umum, elemen-elemen dalam modal intelektual dibedakan dalam tiga kategori pengetahuan, yaitu pengetahuan yang berhubungan dengan karyawan (human capital), pengetahuan yang berhubungan dengan pelanggan (customer capital atau relational capital), dan pengetahuan yang berhubungan hanya dengan perusahaan (structural atau organizational capital). Ketiga kategori tersebut membentuk Intellectual. serta Mekanisme monitoring dan family governance yang memerlukan perhatian lebih dari pengambil keputusan, investor dan perbankan serta para pelaku usaha kecil dan menengah sendiri. Dalam rangka menerapkan mekanisme monitoring yang efektif, peran dewan komisaris dan direksi mengikuti aturan tentang perseroan. Sementara persekutuan perlu membakukan adanya dewan penasehat terdiri dari seluruh sekutu/partners serta peran konsultan eksternal terkait aspek akuntansi. Selanjutnya, pada perseorangan para owner-manager perlu mengoptimalkan adanya konsultan untuk usaha kecil dan menengahendapatkan perspektif alternatif pilihan dalam pengambilan keputusan. Praktik SDM yang baik, family governance, diperlukan dalam rangka memberikan kepastian agar hubungan bisnis-keluarga dapat dikelola[.]

\section{REFERENSI}

Abdurrahman Fathoni. Organisasi dan Manajemen Sumber Daya Manusia. Jakarta: PT Rineka Cipta, 2006.

B. Boekestein. "The relation between intellec- tual capital and intangible assets of phar- maceutical companies" Vol. 7 No.2 (2006).

Bank Indonesia. “data PDB," 2015.

Bontis, N., W. C. C. Keow and S. Richardson. "Intellectual capital and business performance in Malaysian industries" 1(1) (2000): 85- 100 .

Bontis,N., Crossan, M, dan Hulland, J. "Managing an Organizational Learning System by Aligning Stocks and Flows, : .," Journal of Management Studies 39, 2001.

Edi Suharto. Membangun Masyarakat Memberdayakan Rakyat (Kajian Strategis Pembangunan Kesejahteraan Sosial dan Pekerjaan Sosial). Bandung: PT Refika Aditama, 2009. 
Gede, dan I Gusti. Pengaruh Prinsip-Prinsip Good Corporate Governance pada Kinerja Keuangan Koperasi di Kabupaten Klungkung. Bali: Fakultas Ekonomi dan Bisnis Universitas Udayana, 2016.

Iorpev, L. "Does Bank Size Master to Smalland Medium Scale Enterprises (SMEs) Financingin Negeria?" 2(3) (2012).

Jaswadi. Penerapan Good Governance pada Perusahaan Skala Kecil dan Menengah Non Go Public. Malang: Politeknik Negeri Malang, 2016.

Malayu Hasibuan. Manajemen Sumber daya Manusia. Jakarta: PT. Bumi Aksara, 2003.

Marsch, K., Schmieder, C, dan Aerssen , K.F. "Banking Consolidation and Small Business Finance Empirical Evidence." dipresentasikan pada Discussion Paper, Germany, 2007.

Mawardi, M Kholid. "Pengembangan Usaha Kecil dan Menengah (UKM)," t.t., 18.

Oktafia, Yufenti. "Pengaruh Good Corporate Governance," t.t., 22.

Profil Bisnis Usaha Mikro, Kecil dan Menengah (UMKM). Kerjasama LPPI dengan Bank Indonesia, 2015.

Setyani, Nur Hidayati. “Pada Perbankan Syari'ah Di Indonesia,” 2012, 14.

Suandi, dan Y. Sri. Strategi Pengembangan Usaha Mikro Kecil dan Menengah di Provinsi Daerah Istimewa Yogyakarta. Yogyakarta: tp, 2011.

Sulistyastuti, Dyah Ratih. “Dinamika Usaha Kecil Dan Menengah (UKM) Analisis Konsentrasi Regional UKM di Indonesia 1999200" 9, no. 2 (2004): 22.

Veithzal Rivai. Manajemen Sumber Daya Manusia Untuk Perusahaan dari Teori ke Praktik. Jakarta: PT Raja Grafindo Persada, 2005.

Wahab, E. A. A., How, J. C. Y., dan Verhoeven, P. “The Impact of the Malaysian Code on Corporate Governance: Compliance, Institutional Investors, and Stock Performance." 3(2), (2007): 106-129. 
W.D. Bygrave. ““'Small Business Managers' Attitudes Towards And Use Of Financial Sources,"'” 2 (1995): 139-154.

Yasin, Hasbi, Darwanto Darwanto, dan Hari Susanta Nugraha. "Perbaikan Manajemen UKM melalui Kartu Biaya Pesan Produksi." E-DIMAS 9, no. 1 (28 Maret 2018): 98. https://doi. org/10.26877/e-dimas.v9i1.1746.

Zainul Arifin. Dasar-dasar Manajemen Bank Syariah. Jakarta: Pustaka Alvabet, 2005. 
